\title{
INFLUENCE OF LIME ON THE ACCUMULATION OF MINERAL NITROGEN IN INCUBATION EXPERIMENTS OF PEAT SOILS
}

\author{
By \\ Armi Kaila and Sylvi Soini \\ Department of Agricultural Chemistry, University of Helsinki
}

Received October 1, 1957

Generally, liming of acid soils is supposed to have a stimulating effect on the mineralization of organic nitrogen. Although the nitrification of ammonia probably benefits from the decrease in acidity more than does the ammonification or the proper mineralization process, the latter is also claimed to be more intensive in less acid soils. This, however, does not mean that liming would always increase the total amount of mineral nitrogen: the denitrification and the microbiological immobilization of mineral nitrogen may also be stimulated by liming in such a degree that the net result remains low.

In a previous publication (2) the authors found that in incubation experiments liming of peat soils did not always increase even the amount of nitrate nitrogen and in several cases the accumulation of mineral nitrogen was decreased by liming. In order to study this problem in more detail further incubation experiments were arranged, and the results of some of them are reported in the present paper.

\section{Material and methods}

The material of this study consisted of 13 samples from virgin peat soils. All the samples were air-dried and ground which means that the amount of mobilizeable nitrogen in them was probably higher than it had been in fresh samples.

Some characteristics of these peat samples are reported in Table 1. There are 6 samples in which the Sphagnum remains are dominant, the other 7 samples represent peat of a better quality. Most of the samples ${ }^{\circ}$ come from the surface layers, only three of them were taken from deeper deposits. Generally, the degree of humification is rather low, only the three LCp-samples $9-11$ are well humified. The weight of volume and the ash content indicate that there was no marked amount of mineral matter in these samples except perhaps in number 11. Most of the samples are distinctly acid and, generally, also their content of exchangeable calcium is fairly low. The total nitrogen content is equal to that of typical Finnish peat of the corresponding kind. 
Table 1. Peat samples.

\begin{tabular}{|c|c|c|c|c|c|c|c|c|c|c|c|}
\hline No & $\begin{array}{l}\text { Kind of } \\
\text { peat }\end{array}$ & $\mathrm{H}$ & $\begin{array}{l}\text { Depth } \\
\text { dm }\end{array}$ & $\begin{array}{l}\text { Weight of } \\
\text { volume }\end{array}$ & $\begin{array}{c}\text { Ash } \\
\%\end{array}$ & $\mathrm{pH}$ & $\begin{array}{c}\text { Exchangeable } \\
\text { Ca \% }\end{array}$ & $\begin{array}{c}\text { Tot. N } \\
\%\end{array}$ & $\begin{array}{l}\mathrm{NH}_{4}-\mathrm{N} \\
\mathrm{g} / \mathrm{kg}\end{array}$ & $\begin{array}{c}\mathrm{NO}_{3}-\mathrm{N} \\
\mathrm{g} / \mathrm{kg}\end{array}$ & $\begin{array}{r}\text { Min.N } \\
\mathrm{g} / \mathrm{kg}\end{array}$ \\
\hline 1 & Sp & 1 & $0-3$ & 0.10 & 10.7 & 4.0 & 0.20 & 1.24 & 0.23 & 0.12 & 0.35 \\
\hline 2 & CSp & 3 & $0-3$ & 0.27 & 7.8 & 4.7 & 0.28 & 2.99 & 0.20 & 0.06 & 0.26 \\
\hline 3 & CSp & 3 & $4-6$ & 0.20 & 2.7 & 3.9 & 0.21 & 2.98 & 0.49 & 0.01 & 0.50 \\
\hline 4 & $\mathrm{CSp}$ & 4 & $0-3$ & 0.29 & 11.7 & 4.5 & 0.13 & 2.74 & 0.14 & 0.04 & 0.18 \\
\hline 5 & $\operatorname{CSp}$ & 5 & $15-20$ & 0.25 & 4.4 & 4.8 & 0.44 & 2.74 & 0.49 & 0.01 & 0.50 \\
\hline 6 & LCSp & 4 & $0-3$ & 0.27 & 7.5 & 4.5 & 0.26 & 2.47 & 0.35 & 0.07 & 0.42 \\
\hline 7 & $\mathrm{SC}_{\mathrm{p}}$ & 4 & $0-3$ & 0.26 & 4.1 & 4.7 & 0.27 & 3.24 & 0.22 & 0.03 & 0.25 \\
\hline 8 & $\mathrm{LC}_{\mathrm{p}}$ & 4 & $0-3$ & 0.28 & 6.7 & 4.9 & 0.68 & 3.16 & 0.25 & 0.05 & 0.30 \\
\hline 9 & $\mathrm{LC}_{\mathrm{p}}$ & 8 & $0-3$ & 0.46 & 9.1 & 4.7 & 1.32 & 2.40 & 0.42 & 0.01 & 0.43 \\
\hline 10 & $\mathrm{LC}_{\mathrm{p}}$ & 8 & $3-6$ & 0.32 & 7.8 & 4.5 & 1.34 & 2.18 & 0.29 & 0.01 & 0.30 \\
\hline 11 & $\mathrm{LC}_{\mathrm{p}}$ & 8 & $1-6$ & 0.55 & 23.6 & 5.1 & 0.77 & 2.30 & 0.15 & 0.01 & 0.16 \\
\hline 12 & $\mathrm{EuSC}_{p}$ & 3 & $0-3$ & 0.21 & 7.2 & 5.6 & 1.40 & 2.21 & 0.11 & 0.15 & 0.26 \\
\hline 13 & $\mathrm{BC}_{\mathrm{p}}$ & 3 & $0-3$ & 0.21 & 4.7 & 4.7 & 0.43 & 3.16 & 0.12 & 0.06 & 0.18 \\
\hline
\end{tabular}

It is noteworthy that the amount of mineral nitrogen is rather high in all of the samples. This is due to the high content of ammonium-nitrogen which probably is caused by the fact that during the drying, although it was performed at a fairly low temperature (not higher than $20^{\circ} \mathrm{C}$ ), a part of the organic nitrogen may be divided into simple soluble organic compounds which the destillation turns into ammonia. Also it must be remembered that the nitrogen content is expressed on the weight basis and the volume weight of most of these samples is extremely low.

No nitrite-nitrogen was found in these samples.

The incubation was carried out in glass jars. The peat samples were moistened to 70 per cent of their total water-holding capacity. All treatments were in duplicates. Analyses were performed without drying the samples.

$p H$ was measured in water suspension $(1: 4)$ using a Beckman $\mathrm{pH}$-meter with glass electrode.

Ammonium-nitrogen was in previous experiments extracted with a $10 \% \mathrm{KCl}$ solution (2). In this study the less expensive $0.1 \mathrm{~N} \mathrm{HCl}$ was used. This acid was found to extract from the peat samples somewhat less organic nitrogen than did the $\mathrm{KCl}$-solution and this probably was one reason for the slightly lower figures for ammonium-nitrogen obtained with the $\mathrm{HCl}$-extraction as compared with those given by the potassium chloride treatment.

The determination of ammonium-nitrogen was performed by shaking $20 \mathrm{~g} \mathrm{sam-}$ ples of fresh incubated peat in $100 \mathrm{ml}$ of $0.1 \mathrm{~N} \mathrm{HCl}$, for one hour, and by filtrating and washing the soil twice with $25 \mathrm{ml}$ of the extractant. The ammonia in the extract was determined by destillation with $\mathrm{MgO}$.

Nitrate-nitrogen was extracted from fresh $20 \mathrm{~g}$ samples with $100 \mathrm{ml}$ of saturated calcium sulphate solution in which the samples were shaken for five minutes. The determination was performed from the filtrate by the phenoldisulphonic acid method using an EEL-colorimeter.

The presence of nitrite-nitrogen was estimated ocularly on the basis of the red colour produced by the Griesss reagent in the calcium sulphate extract. 
Table 2. Mineral nitrogen in unlimed and limed peat samples incubated for four months at $7^{\circ} \mathrm{C}$.

(Expressed as $\mathrm{N} \mathrm{g} / \mathrm{kg}$ ).

\begin{tabular}{|c|c|c|c|c|c|c|c|c|c|}
\hline \multicolumn{2}{|c|}{ Sample } & \multicolumn{2}{|c|}{$\mathrm{pH}$} & \multicolumn{2}{|c|}{$\mathrm{NH}_{4}-\mathrm{N}$} & \multicolumn{2}{|c|}{$\mathrm{NO}_{3}-\mathrm{N}$} & \multicolumn{2}{|c|}{ Min. N } \\
\hline 1. & Sp & $\frac{O}{4.7}$ & $\frac{\mathrm{CaCO}_{3}}{6.0}$ & $\begin{array}{c}\mathrm{O} \\
0.50\end{array}$ & $\frac{\mathrm{CaCO}_{3}}{0.55}$ & $\begin{array}{c}0 \\
0.04\end{array}$ & $\begin{array}{c}\mathrm{CaCO}_{3} \\
0.03\end{array}$ & $\frac{O}{0.54}$ & $\frac{\mathrm{CaCO}_{3}}{0.58}$ \\
\hline 2. & $\mathrm{CS}_{\mathrm{p}}$ & 5.5 & 6.1 & 0.52 & 0.66 & 0.03 & 0.05 & 0.55 & 0.71 \\
\hline 3. & $\mathrm{CSp}$ & 4.5 & 5.7 & 0.43 & 0.03 & 0.03 & 0.50 & 0.46 & 0.53 \\
\hline 4. & $\mathrm{CSp}$ & 5.4 & 6.0 & 0.21 & 0.31 & 0.03 & 0.02 & 0.24 & 0.33 \\
\hline 5. & $\mathrm{CSp}$ & 5.5 & 6.5 & 0.36 & 0.38 & 0.01 & 0.02 & 0.37 & 0.40 \\
\hline 6. & LCSp & 5.5 & 6.3 & 0.66 & 0.77 & 0.07 & 0.08 & 0.73 & 0.85 \\
\hline 7. & $\mathrm{SC}_{\mathrm{p}}$ & 5.7 & 6.6 & 0.80 & 1.00 & 0.06 & 0.15 & 0.86 & 1.15 \\
\hline 8. & $\mathrm{LC}_{\mathrm{p}}$ & 5.8 & 6.4 & 0.88 & 1.00 & 0.06 & 0.10 & 0.94 & 1.10 \\
\hline 9. & $\mathrm{LC}_{\mathrm{p}}$ & 5.3 & 5.5 & 0.47 & 0.03 & 0.29 & 0.72 & 0.76 & 0.75 \\
\hline 10. & $\mathrm{LC}_{\mathrm{p}}$ & 6.0 & 6.2 & 0.32 & 0.08 & 0.17 & 0.39 & 0.49 & 0.47 \\
\hline 11. & $\mathrm{LC}_{\mathrm{p}}$ & 4.9 & 5.4 & 0.42 & 0.45 & 0.01 & 0.01 & 0.43 & 0.46 \\
\hline 12. & $\operatorname{EuSC}_{p}$ & 6.2 & 6.3 & 0.45 & 0.35 & 0.01 & 0.01 & 0.46 & 0.36 \\
\hline 13. & $\mathrm{BCp}$ & 5.6 & 5.9 & 0.64 & 0.59 & 0.03 & 0.03 & 0.67 & 0.62 \\
\hline \multicolumn{4}{|c|}{ Significant difference at 5 per cent level } & \multicolumn{2}{|c|}{0.07} & \multicolumn{2}{|c|}{0.05} & \multicolumn{2}{|c|}{0.07} \\
\hline
\end{tabular}

\section{Experiments}

Three series of incubations were carried out. In the first the effect of lime on the accumulation of mineral nitrogen at a fairly low temperature was studied. The object of the second experiment was the effect of the amount of lime applied, and, in addition to this, the third series also contained a treatment with nitrogen fertilizers.

The first incubation experiment covered all the 13 peat samples. Calcium carbonate was applied in such amounts that the $\mathrm{pH}$-value of the peat increased to about $\mathrm{pH} 6$ in water suspension. The experiment was carried out at $7^{\circ} \mathrm{C}$, and the incubation period was four months. The results are reported in Table 2 .

The $\mathrm{pH}$-values of the unlimed samples are rather high, generally distinctly higher than those of the original material. Probably, this is due to the accumulation of ammonia (cf. 1). In most of the samples the difference caused by the lime is not very marked.

The ammonium-nitrogen content appears to be slightly increased by liming in five of the peats: in CSp-samples 2 and 4, LCSp-sample 6, SCp-sample 7, and LCpsample 8. In samples 3. CSp, 9. LCp, and 10. LCp a marked drop in the ammoniumnitrogen content was caused by lime, which corresponds to an increase in the nitratenitrogen content. In $\mathrm{SC}_{\mathrm{p}}$ sample 7 also the nitrate-nitrogen content is somewhat higher in the limed pots, but in all the other samples no nitrate-nitrogen formation can be detected either in the limed or unlimed samples.

Since no nitrite-nitrogen was found in these samples the sum of ammonium- and nitrate-nitrogen represents the total amounts of mineral nitrogen. This is, of course, the most important figure as an indicator of the plant-available nitrogen in peat 
Table 3. Mineral nitrogen in peat samples incubated with different amounts of lime.

(Expressed as $\mathrm{N} \mathrm{g/kg).}$

\begin{tabular}{|c|c|c|c|c|c|c|c|c|}
\hline \multirow{2}{*}{$\begin{array}{l}\text { Treat } \\
\text { ment }{ }^{1}\end{array}$} & \multicolumn{4}{|c|}{ Incubated for 4 months at $9-15^{\circ} \mathrm{C}$} & \multicolumn{4}{|c|}{ Incubated for 12 months at $0-15^{\circ} \mathrm{C}$} \\
\hline & $\mathrm{pH}$ & $\mathrm{NH}_{4}-\mathrm{N}$ & $\mathrm{NO}_{3}-\mathrm{N}$ & Min. $\mathrm{N}$ & $\mathrm{pH}$ & $\mathrm{NH}_{4}-\mathrm{N}$ & $\mathrm{NO}_{3}-\mathrm{N}$ & Min. $\mathrm{N}$ \\
\hline \multicolumn{9}{|l|}{ 1. $\mathrm{Sp}$} \\
\hline 0 & 4.8 & 0.55 & 0.07 & 0.62 & 5.0 & 0.92 & 0.09 & 1.01 \\
\hline $\mathrm{Ca} 4$ & 5.8 & 0.62 & 0.07 & 0.69 & 4.5 & 0.20 & 0.84 & 1.04 \\
\hline Ca 8 & 7.1 & 0.59 & 0.09 & 0.68 & 4.6 & 0.21 & 0.83 & 1.04 \\
\hline \multirow[t]{2}{*}{ Ca 12} & 8.0 & 0.40 & 0.24 & $(0.64)^{2}$ & 5.4 & 0.19 & 0.77 & 0.96 \\
\hline & & $0.13^{*}$ & $0.07^{*}$ & $0.13^{*}$ & & $0.13^{*}$ & $0.30^{*}$ & $0.27^{*}$ \\
\hline \multicolumn{9}{|l|}{ 5. CSp } \\
\hline 0 & 5.4 & 0.28 & 0.02 & 0.30 & 5.4 & 0.40 & 0.04 & 0.44 \\
\hline $\mathrm{Ca} 4$ & 6.0 & 0.33 & 0.02 & 0.35 & 5.4 & 0.32 & 0.05 & 0.37 \\
\hline Ca 8 & 6.5 & 0.37 & 0.03 & 0.40 & 5.3 & 0.34 & 0.11 & 0.45 \\
\hline \multirow[t]{2}{*}{ Ca 12} & 6.9 & 0.35 & 0.04 & 0.39 & 5.8 & 0.31 & 0.15 & 0.46 \\
\hline & & $0.03^{*}$ & $0.02^{*}$ & $0.02^{*}$ & & $0.10^{*}$ & $0.14^{*}$ & $0.19^{*}$ \\
\hline \multicolumn{9}{|l|}{ 7. $\mathrm{SC}_{\mathrm{p}}$} \\
\hline 0 & 5.6 & 1.12 & 0.09 & 1.21 & 4.5 & 0.26 & 0.39 & 0.65 \\
\hline $\mathrm{Ca} 4$ & 5.6 & 0.86 & 0.39 & 1.25 & 4.5 & 0.05 & 1.31 & 1.36 \\
\hline Ca 8 & 5.8 & 0.62 & 0.66 & $(1.28)^{2}$ & 4.6 & 0.05 & 1.45 & 1.50 \\
\hline \multirow[t]{2}{*}{ Ca 12} & 6.4 & 0.30 & 0.77 & $(1.07)^{2}$ & 4.8 & 0.05 & 1.66 & 1.71 \\
\hline & & $0.26^{*}$ & $0.19^{*}$ & $0.13^{*}$ & & $0.09 *$ & $0.18^{*}$ & $0.18^{*}$ \\
\hline \multicolumn{9}{|l|}{ 10. $\mathrm{LC}_{\mathrm{p}}$} \\
\hline 0 & 5.2 & 0.01 & 0.44 & 0.45 & 5.2 & 0.05 & 0.55 & 0.60 \\
\hline $\mathrm{Ca} 4$ & 5.5 & 0.02 & 0.47 & 0.49 & 5.2 & 0.06 & 0.62 & 0.63 \\
\hline Ca 8 & 5.9 & 0.02 & 0.49 & 0.51 & 5.2 & 0.06 & 0.62 & 0.68 \\
\hline \multirow[t]{2}{*}{ Ca 12} & 6.2 & 0.02 & 0.50 & 0.52 & 5.2 & 0.04 & 0.65 & 0.69 \\
\hline & & $0.01^{*}$ & $0.07^{*}$ & $0.08^{*}$ & & $0.07 *$ & $0.20^{*}$ & $0.17^{*}$ \\
\hline \multicolumn{9}{|l|}{ 13. $\mathrm{BC}_{\mathrm{p}}$} \\
\hline 0 & 5.4 & 0.58 & 0.04 & 0.62 & 5.5 & 0.60 & 0.25 & 0.85 \\
\hline $\mathrm{Ca} 4$ & 6.2 & 0.55 & 0.05 & 0.60 & 5.4 & 0.38 & 0.47 & 0.85 \\
\hline Ca 8 & 6.7 & 0.42 & 0.07 & 0.49 & 5.4 & 0.15 & 0.68 & 0.83 \\
\hline \multirow[t]{2}{*}{ Ca 12} & 7.1 & 0.33 & 0.17 & $(0.50)^{2}$ & 5.7 & 0.07 & 0.82 & 0.89 \\
\hline & & $0.10^{*}$ & $0.03^{*}$ & $0.10^{*}$ & & $0.64^{*}$ & $0.54^{*}$ & $0.22^{*}$ \\
\hline
\end{tabular}

* Significant difference at 5 per cent level

${ }_{1} \mathrm{Ca} 4=\mathrm{CaCO}_{3} 4000 \mathrm{~kg} / \mathrm{ha}, \mathrm{Ca} 8=\mathrm{CaCO}_{3} 8000 \mathrm{~kg} / \mathrm{ha}, \mathrm{Ca} 12=\mathrm{CaCO}_{3} 12000 \mathrm{~kg} / \mathrm{ha}$.

2 Contained some nitrite-nitrogen

soils. The data reveal that only in five peat samples, in 2. CSp, 4. CSp, 6. LCSp, 7. $\mathrm{SCp}$, and $8 . \mathrm{LC}_{\mathrm{p}}$, the mineral nitrogen content is higher in the limed than in the unlimed pots. In the EuSCp-sample 12 a significant, although not high decrease in the mineral nitrogen content owing to the liming can be noticed. In all the other 
cases lime has had no effect on the total amount of mineral nitrogen under the conditions of this experiment.

In the second incubation experiment the amounts of lime applied corresponded to 4000,8000 , and $12000 \mathrm{~kg} / \mathrm{ha}$ of calcium carbonate, respectively. The experiment was started in May. The temperature in the basement room where the pots were placed was during the first weeks about $9-10^{\circ} \mathrm{C}$. Later in the summer a maximum temperature of $15^{\circ} \mathrm{C}$ was reached. During the winter months the temperature dropped again and in January and February it was only about $0^{\circ} \mathrm{C}$. Analyses were performed in September and in the following May, i.e. after incubation periods of four months and twelve months.

The results of this experiment with five peat samples are reported in Table 3 . In the $\mathrm{pH}$-values of the samples incubated for four months the effect of liming is more or less distinct, but during the continued incubation the differences between the acidity of the variously treated samples decreased markedly. Observations of this kind are typical regarding the behaviour of limed peat soils (1).

In the Sp-samples incubated for four months only the highest amount of lime was able to cause some nitrification of the ammonium-nitrogen. In the samples incubated for twelve months the effect of the lowest application appears to be equal to that of the larger ones. Liming has not changed the amount of mineral nitrogen accumulated in this Sp-sample.

It is noteworthy that in the Sp-sample which was treated with $12000 \mathrm{~kg} / \mathrm{ha}$ of lime and the $\mathrm{pH}$ of which was 8.0 , some nitrite-nitrogen was detected. Nitrite-nitrogen was also found in the SCp-samples limed with 8000 and $12000 \mathrm{~kg} / \mathrm{ha}$ and in the $\mathrm{BCp}$ sample treated with the highest amount of lime. During prolonged incubation the nitrite-nitrogen disappeared.

In the fairly well humified CSp-sample all the applications of lime have slightly increased both the amounts of ammonium-nitrogen and the total mineral nitrogen in the samples incubated for four months. In the samples incubated for twelve months no differences due to lime may be detected.

In the SCp-sample also the lower amounts of lime brought about marked nitrification in the first four months. During prolonged incubation this effect was further intensified, also the total amount of mineral nitrogen accumulated was the greater the higher the application of lime. In the very well humified LCp-samples, on the other hand, a fairly intensive nitrification occurred regardless of the rate of liming.

In the $\mathrm{BCp}$-samples some nitrification of ammonium-nitrogen was brought about by liming. In the samples incubated for four months a slight loss of mineral nitrogen in the heavily limed samples may be detected. The large variation makes it impossible to draw any definite conclusions on the the effect of lime on the nitrification during the prolonged incubation. However, the total amounts of mineral nitrogen appear to be equal in all the treatments.

In the third incubation experiment one half of the pots were treated with ammonium nitrate, and the effects of increasing amounts of lime on the ammonium- and nitrate-nitrogen contents of peat samples were studied. The application of mineral nitrogen corresponded to $100 \mathrm{~kg} / \mathrm{ha}$ of $\mathrm{N}$. In the SCp-samples this means $0.18 \mathrm{~g} / \mathrm{kg}$ of $\mathrm{N}$, in the $\mathrm{BCp}$-samples it corresponds to $0.24 \mathrm{~g} / \mathrm{kg}$ of $\mathrm{N}$. In both cases one half of 
Table 4. Mineral nitrogen in peat samples incubated with increasing amounts of lime with or without an application of ammonium nitrate. (Expressed as $\mathrm{N} \mathrm{g} / \mathrm{kg}$ ).

\begin{tabular}{|c|c|c|c|c|c|c|c|c|c|c|}
\hline \multirow{3}{*}{$\begin{array}{l}\text { Sample } \\
\text { 7. } \mathrm{SCp}_{\mathrm{p}}\end{array}$} & \multirow{3}{*}{$\begin{array}{c}\begin{array}{c}\text { Incubation } \\
\text { period } \\
\text { months }\end{array} \\
41 / 2\end{array}$} & \multirow{3}{*}{$\begin{array}{c}\begin{array}{c}\text { Treat- } \\
\text { ment }\end{array} \\
0\end{array}$} & \multirow{3}{*}{\multicolumn{2}{|c|}{$\begin{array}{l}\frac{\mathrm{pH}}{\mathrm{NH}_{4} \mathrm{NO}_{3}} \\
5.6\end{array}$}} & \multicolumn{2}{|c|}{$\mathrm{NH}_{4}-\mathrm{N}$} & \multicolumn{2}{|c|}{$\mathrm{NO}_{3}-\mathrm{N}$} & \multirow{2}{*}{\multicolumn{2}{|c|}{$\frac{\text { Min. N }}{0 \mathrm{NH}_{4} \mathrm{NO}_{3}}$}} \\
\hline & & & & & \multicolumn{2}{|c|}{$0 \mathrm{NH}_{4} \mathrm{NO}_{3}$} & \multicolumn{2}{|c|}{$0 \mathrm{NH}_{4} \mathrm{NO}_{3}$} & & \\
\hline & & & & & 0.85 & 0.90 & 0.09 & 0.16 & 0.94 & 1.06 \\
\hline & & $\mathrm{Ca} 4$ & 6.2 & 6.1 & 1.00 & 1.00 & 0.11 & 0.19 & 1.11 & 1.19 \\
\hline & & Ca 8 & 6.8 & 6.7 & 1.09 & 1.11 & 0.13 & 0.22 & 1.22 & 1.33 \\
\hline & & Ca 12 & 7.1 & 7.3 & 0.95 & 1.01 & 0.07 & 0.25 & 1.02 & 1.26 \\
\hline & & & & & \multicolumn{2}{|c|}{$0.09 *$} & \multicolumn{2}{|c|}{$0.06^{*}$} & \multicolumn{2}{|c|}{$0.14^{*}$} \\
\hline & \multirow[t]{5}{*}{10} & 0 & 5.6 & 5.7 & 1.17 & 1.19 & 0.04 & 0.11 & 1.21 & 1.30 \\
\hline & & $\mathrm{Ca} 4$ & 5.1 & 5.6 & 0.29 & 0.55 & 0.63 & 0.58 & 0.92 & 1.13 \\
\hline & & Ca 8 & 4.9 & 5.3 & 0.13 & 0.12 & 1.02 & 0.85 & 1.15 & 0.97 \\
\hline & & Ca 12 & 5.2 & 5.4 & 0.12 & 0.08 & 0.84 & 0.89 & 0.96 & 0.97 \\
\hline & & & & & \multicolumn{2}{|c|}{$0.06^{*}$} & \multicolumn{2}{|c|}{$0.18^{*}$} & \multicolumn{2}{|c|}{$0.19^{*}$} \\
\hline \multirow[t]{10}{*}{ 13. $\mathrm{BCp}$} & $4 \quad 1 / 2$ & 0 & 6.1 & 6.1 & 0.63 & 0.85 & 0.05 & 0.22 & 0.68 & 1.07 \\
\hline & & $\mathrm{Ca} 4$ & 6.9 & 7.0 & 0.54 & 0.73 & 0.07 & 0.23 & 0.61 & 0.96 \\
\hline & & Ca 8 & 7.6 & 7.5 & 0.43 & 0.54 & 0.08 & 0.24 & 0.51 & 0.78 \\
\hline & & Ca 12 & 8.1 & 8.1 & 0.29 & 0.34 & 0.10 & 0.25 & 0.39 & 0.59 \\
\hline & & & & & \multicolumn{2}{|c|}{$0.10^{*}$} & \multicolumn{2}{|c|}{$0.03^{*}$} & \multicolumn{2}{|c|}{$0.11^{*}$} \\
\hline & \multirow[t]{5}{*}{10} & 0 & 5.8 & 6.0 & 0.70 & 0.83 & 0.04 & 0.12 & 0.74 & 0.95 \\
\hline & & $\mathrm{Ca} 4$ & 5.9 & 6.0 & 0.62 & 0.74 & 0.08 & 0.20 & 0.70 & 0.94 \\
\hline & & Ca 8 & 5.9 & 6.1 & 0.11 & 0.15 & 0.41 & 0.51 & 0.52 & 0.66 \\
\hline & & Ca 12 & 6.2 & 6.0 & 0.10 & 0.11 & 0.35 & 0.51 & 0.45 & 0.62 \\
\hline & & & & & \multicolumn{2}{|c|}{$0.08^{*}$} & \multicolumn{2}{|c|}{$0.09^{*}$} & \multicolumn{2}{|c|}{$0.11^{*}$} \\
\hline
\end{tabular}

* Significant difference at 5 per cent level

if was ammonium-nitrogen and the other half nitrate-nitrogen. Lime was applied in quantities corresponding to 4000,8000 , and $12000 \mathrm{~kg} / \mathrm{ha}$ of calcium carbonate respectively. The incubation was carried out at $7^{\circ} \mathrm{C}$. Analyses were performed after periods of $4 \frac{1}{2}$ months and 10 months. The results are reported in Table 4.

The effect of lime on the untreated and treated samples appears to be almost equal. In $\mathrm{SC}_{\mathrm{p}}$ samples incubated for the shorter period liming seems to have enhanced the rate of ammonification thus causing a slight increase in the total amount of mineral nitrogen accumulated. In $\mathrm{BC}$-samples, however, the ammonium-nitrogen content and also the content of total mineral nitrogen were the lower the more intensive the liming. The reason may be found in the high $\mathrm{pH}$-values of the $\mathrm{BCp}$-samples which allow for quite considerable losses of ammonia by volatilizing (c.f. 3). During the prolonged incubation no marked change in the total mineral nitrogen content of the $\mathrm{BC}$-samples occurred. In the $\mathrm{SCp}$-samples a slight trend towards a decrease in mineral nitrogen may be found in the heavily limed pots. 
Owing to the large variation in the results the fate of the applied mineral nitrogen cannot be proved. In the $\mathrm{BC}$-samples the nitrogen content seems to be significantly higher than in the corresponding untreated pots, yet the difference is generally lower than the amount of mineral nitrogen added. In the $\mathrm{SCp}$-samples the mineral nitrogen application can be found only in the values for nitrate-nitrogen in the samples incubated for $4 \frac{1}{2}$ months.

\section{Discussion}

The results reported in this paper are in accordance with our previous observations: liming of peat samples does not always enchance the accumulation of mineral nitrogen in incubation experiments. In fourteen cases no effect of lime was found, in four cases somewhat lower amounts of mineral nitrogen were detected in the limed samples than in the unlimed ones, and in eight cases liming exerted a positive effect which was marked, however, only in three cases. The results did not seem to depend on the type of peat.

There are several explanations of these results. In some cases the $\mathrm{pH}$-value of the peat material may be increased by liming in such a degree that a marked volatilization of ammonium-nitrogen might occur. This probably applies to some of the samples in the experiments two and three when 8000 or $12000 \mathrm{~kg} / \mathrm{ha}$ of calcium carbonate were applied. It is difficult to estimate what part the proper denitrification process plays in these cases, but attention must possibly be paid to this kind of nitrogen loss as well as to the fact that the nitrification itself may often occur with distinct losses of nitrogen.

Further, there is the microbial immobilization of nitrogen at the expence of carbon compounds the availability of which may be improved by the liming. However, owing to the high content of organic nitrogen in these peat samples it seems that only a temporary net-immobilization of mineral nitrogen might occur.

On the other hand, it is possible that the rather poor final effect of lime in these incubation experiments is not caused by losses of nitrogen but by the fact that high acidity has not been the minimum factor in the mobilization. The fairly high $\mathrm{pH}$ values found in several of the unlimed samples indicate that ammonification and perhaps also some other reactions can markedly decrease the acidity, even at the rather low temperatures at which the present experiments were carried out.

The present results were obtained under quite artificial conditions, and probably they say very little of the corresponding processes in nature. First of all the fact must be remembered that the plants are able to utilize ammonium-nitrogen. Therefore, the nitrification process is not necessary, and, provided that the losses of nitrogen are connected with the oxidation of ammonium-nitrogen under soil conditions, the nitrification may even be considered a harmful reaction. In any case, the most important process is the release of ammonium-nitrogen from organic compounds, and it is the rate of this proper mobilization which determines the nitrogen nutrition of plants. Unfortunately the present incubation experiments do not give any idea of the effect of liming on this process. 
Thus it seems that the problem of the effect of liming upon the mineralisation of peat nitrogen is complex, and deserves more study particularly with regard to the different phases of the changes of nitrogen forms in soil.

\section{$S u m m$ ary}

In the present paper the effect of lime on the mobilization of peat nitrogen was studied using incubation experiments under laboratory conditions.

In the first experiment in which 13 samples of virgin peat soils were incubated for four months at $7^{\circ} \mathrm{C}$, lime caused a marked nitrification of ammonium nitrogen in three samples, and a fairly low increase in the ammonium nitrogen content of five samples. The accumulation of total mineral nitrogen was benefited by lime in five samples and only in one of them could a marked increase be detected.

In the second experiment the amounts of lime applied to five peat samples corresponded to 4000,8000 or $12000 \mathrm{~kg} / \mathrm{ha}$ of $\mathrm{CaCO}_{3}$. At the end of an incubation period of four months at $9-15^{\circ} \mathrm{C}$ the total amounts of mineral nitrogen accumulated did not depend on the fate of liming, as did the nitrification in $\mathrm{SCp}$-and $\mathrm{BC}$-samples, and also, in part, in the Sp- and CSp-samples. After the prolonged incubation up to 12 months the amount of lime applied had little or no effect upon the accumulation of nitrate-nitrogen or total mineral nitrogen except in the SCp-sample in which a positive correlation between these figures existed. Traces of nitrite-nitrogen were detected in some of the samples incubated for four months with the heaviest applications of lime.

In the third experiment carried out at $7^{\circ} \mathrm{C}$ the treatment with lime was equal to that in the second series, but half of the pots were treated with ammonium nitrate corresponding to $100 \mathrm{~kg} / \mathrm{ha}$ of nitrogen. The effect of lime on the treated samples appeared to be similar to that in the untreated one. Owing to the large variation, the fate of applied mineral nitrogen could not be distinctly detected. The loss of ammonium nitrogen through volatilization from the most heavily limed pots may be a possible explanation for the lower amounts of total mineral nitrogen in the incubated BCp-samples.

Some reasons for these variable results are discussed and attention is also paid to the importance of nitrification on the nitrogen nutrition of plants.

\section{REFERENCES}

(1) Kalla, A. 1954. Nitrification in decomposing organic matter. Acta agric. scand. 4: $17-32$.

(2) $\longrightarrow$ Sorni, S. \& Krvinen, E. 1954. Influence of lime and fertilizers upon the mineralization of peat nitrogen in incubation experiments. J. Sci. Agric. Soc. Finland 26: $79-59$.

(3) TuorilA, P. 1929. Bindungsvermögen verschiedener Torfarten für Stickstoff in Form von Ammoniak. Wissenschaft. Veröffent. Finnischen Moorkulturvereins No 9, Helsinki, 47 p. 
S E L O S T U S :

\title{
KALKITUKSEN VAIKUTUKSESTA MINERAALITYPEN KERTYMISEEN TURVE- NÄYTTEITÄ MUHITETTAESSA
}

\author{
Armi Kaila ja Sylvi Sorni
}

\section{Yliopiston maanviljelyskemian laitos, Helsinki}

Maanviljelyskemian laitoksen aikaisemmissa muhituskokeissa (2) todettiin, ettei kalkitus läheskään aina vaikuttanut edullisesti mineraalitypen kertymiseen, ei edes nitraattitypen määrä ollut aina suurempi kalkituissa kuin kalkitsemattomissa koejäsenissä. Samanlaisiin tuloksiin päädyttiin edellä selostetuissa koesarjoissa, joissa kolmeatoista luonnontilaisilta soilta otettua turvenäytettä muhitettiin erilaisissa olosuhteissa. Kalkituksen vaikutus ei näyttänyt riippuvan turpeen laadusta.

Syynä siihen, että kalkitus voi tällaisissa kokeissa vähentää kertyvän mineraalitypen määrää, saattaa olla eräissä tapauksissa ammoniakin häviö haihtumalla liian korkeaan pH-arvoon kalkitusta näytteestä. Denitrifioitumisella samoin kuin nitrifikaatioon liittyvillä typen häviöillä lienee myös merkityksensä, mutta typen mikrobiologinen pidättyminen ei voine muuta kuin tilapäisesti vähentää mineraalitypen määrää. Toisaalta on todennäköistä, että kalkin puute ja happamuus eivät ole kaikissa tapauksissa typen mobilisoitumista estäviä tekijöitä.

Tällaiset muhituskokeet, joissa voidaan todeta vain ammonifioitumisen, nitrifioitumisen, denitrifioitumisen ja typen mikrobiologisen pidättymisen yhteistulos, eivät anna kuvaa kasvien ravitsemuksen kannalta ratkaisevimmasta seikasta: turpeen orgaanisista yhdisteistä vapautuvan ammoniumtypen määrästä ja vapautumisnopeudesta. 